\title{
Ethnobotanical Studies of Wild Flora at G. Udayagiri Forest In Eastern Ghat, Odisha
}

\author{
${ }^{1}$ A. K. Shadangi, ${ }^{2}$ R. P. Panda, ${ }^{3}$ A. K. Patra \\ Environmental Biology Research laboratory P.G Department of Zoology Utkal University, Vanivihar
}

\begin{abstract}
Ethnobotanical studies on diversity patterns and their economic importance during 2009-2011 have been surveyed. The documentation of data based on taxonomical status of useful flora and their economic importance have been established. 120 potent species belonging to 23 Orders and 55 families have been documented and 37 valuable species have been identified. This study also precautioned to take immediate step to conserve these precious resources before these get extinct.
\end{abstract}

\section{Introduction}

Ethnobotany is a field which elucidates the "cultural position of the tribes who used the plants for food, shelter or clothing" (Harshberger, 1896).

With the advent of human civilization, many systems of therapy have been developed primarily based on plants. Ayurveda, Homeopathy, Sidha, Unani etc. are our traditional systems of medicines. The World Health Organization has estimated that over $80 \%$ of the global population rely chiefly on traditional medicine ( Akerele, 1992).

Ancient ethenic communities of the world had learnt to utilize their neighbourhood herbal flora for various curative as well as offensive purposes (Subramanium and Pushpangadan, 1995).

Survey reports also show that supplies of some of the medicinal raw materials are running short in the pharmaceutical industries in India (Report of Task Force, 2000).

India has more than one fourth (8000) of the world's known medicinal plant species $(30,000)$, of which $90 \%$ are found in the forest habitats (Krishna Kumar and Katakam, 2002).

The All India Ethno-biology Survey estimated that over 7,500 plant species are used by 4,635 ethnic communities for human and veterinary health care across the country. Nearly $80 \%$ of the world populations rely on traditional medicines for primary health care, most of which involve the use of plant extract (Sandhy et al, 2006).

Ethno-medicinal studies have offered immense scope and opportunities for the development of new drugs. Some modern drugs have been deducted from folklore and traditional medicines.

Living close to nature, traditional societies have acquired unique knowledge about the use of wild flora and fauna, most of which are unknown to the people who live away from such natural ecosystem as forests. After years of observations and analysis, trials, error, experimentation or even use of intuitive methods the innovative member of human communities have selected/identified useful and harmful members of the flora and fauna. Majority of kondh population of the district is still using the traditional medicines involving different plant or plant parts against various aliments.

The wealth of traditional knowledge among the people of the district is based on hundreds of years of beliefs and observations. his knowledge has been transmitted orally from generation to generation; however it seems that it is generally diluted and vanishing from the modern society since younger people are not interested to carry on this tradition. Therefore, it warrents the collection and documents of this knowledge before this knowledge is lost for ever.

The present paper deals with the result of exploration of ethnomedicinally important taxa growing in the tribal locality of G.Udayagiri hill forest of kondhamal district, Odisha.

\section{Aim And Objectives}

Today there is an increasing desire to unravel the role of ethnobotanical studies in trapping the centuries old traditional folk knowledge as well as in searching new plant resources of food drug etc (Jain, 1987, 1991).

- To study the flora and fauna of the hill forest and to put them in a systematic and scientific taxonomical groups for academic purposes.

- To assess the economically important plant and animal species and to establish ecological conditions in terms of biotic factors.

- To study economic importance and commercial values as well as academic prospects of this hill ecosystem. 


\section{Materials And Methods}

Kondhamal is a tribal district, located in the central part of Odisha. It extends from $19^{\circ} 36^{\prime}$ to $20^{\circ} 54^{\prime} \mathrm{N}$ Latitude and $80^{\circ} 30^{\prime}$ to $84^{\circ} \mathrm{E}$ Longitude and situated at about 1800 meter above the mean sea level. It spreads an area of $8021 \mathrm{sq} \mathrm{km}, 60 \%$ of which is covered with forest. G.Udayagiri forest is present in eastern part of Kondhamal district of Orissa. It is located in 14-28 N-78-52E.

The Kondhamal district of Odisha harbors a rich diversity of ethnobotanical species, which generate considerable benefits from social and economic perspectives. Until now, people are preparing medicines from their available species of plants, which are used to treat common diseases.

The present study was undertaken during the period 2007 - 2009.

The present paper deals with the result of exploration of ethnomedicinally important taxa growing in the tribal locality of G.Udayagiri hill forest of Kandhamal district.

Data for this work were from the following sources.

- The information available in literatures and official documents of the forest ecosystem.

- Data collected during the course of discussion with research personals and tribals.

- Ethno-botanical studies revealed that the tribes of SBR possess a great amount of indigenous knowledge. Tribal life styles blend harmoniously with nature, and they are considered as 'Ecofriendly people'.

- Data collected through field observations of various spots.

- The wild animals would be noted from direct visual observation, from foot prints, faecal materials (Saharia, 1982).

- The vegetation of the study area and complexed diversity pattern of plants are distributed in different regions. Plants were collected, identified and listed according to flora taxonomy (Haris, 1978) and also medicinal values (Pal and Srivastava, 1979, Chakrabarty, 1980).

\section{Result And Discussion}

The present study revealed that a total of 120 species ethno-medicinal plants belonging to 23 Orders and 55 families have been documented for their therapeutic use against different diseases. For each species botanical name, family, local name, parts used, methods of preparation, administration and ailments treated are provided. Trees ( 51 species) were found to be the most used plants followed by herbs (39 species), shrubs (22 species) and climbers (8 species) in descending order.

During the study it is observed that the family Euphorbiaceae( 8 species) and Fabaceae( 8 species) are dominantly used by the tribals to cure their various ailments followed by Zingiberaceae(6 species), Combretaceae(5 species), Mimosaceae(5 species), Apocynaceae, Moraceae, Anacardiaceae, Caesalpiniaceae, Solanaceae; each of 4 species, Lamiaceae, Acanthaceae, Flacourtiaceae, Rutaceae; each of 3 species , Arecaceae, Ebenaceae, Malvaceae, Apocynaceae(2 species each) etc.

The plant parts used ranged from leaves (68), root (40) whole plant (5), stem bark (39), rhizome (5), fruits (16), flowers (14),Stem (17), latex (3), gum(2), twig(2), oil(6), Sap(2) and resin in one plant.

Medicines were prepared in the form of paste, oil extract, powder, decoction and infusion; three plants are used in all forms. The latex is used as such in three plants. External application is involved in the treatment of various types of skin diseases.

Traditional healers are using these plants to cure many diseases like stomachache, headache, diarrhoea and dysentery, fertility problems, skin problems, cold, fever, cough, toothache, jaundice, wounds, diabetes, asthma, tuberculosis, bone fractures, urinary problems, piles, antidote (snake and scorpion bites), rheumatism and leprosy.

It was observed that, most of the remedies consisted of single plant part and more than one method of preparation. However, many of the remedies consisted of different parts of the same plant species to treat single or more diseases. e.g., Andrographis paniculata - leaf paste is used to treat poison bites and leaf powder is used to treat diabetes.

Moreover a single plant is used for more than one disease. e.g., Andrographis paniculata (diabetes and scorpion bites), Terminalia arjuna(wounds, headache and tooth infections).

Common health problems in the sites of the study area were skin problems such as wounds, cuts, burns and skin diseases and the largest number of the remedies (wounds -16 remedies and skin diseases -13 remedies) was used to treat these troubles. 23 remedies were used to alleviate problems of the respiratory system such as cold, cough and asthma. Most of the plants in Lamiaceae were used to treat cold, cough, fever, headache and asthma. In the present study eight remedies (Terminalia arjuna, Leucas aspera, Ocimum sanctum, Sida acuta, , Lantana camara andVitex negundo) were used to get relief from headache. Pergularia daemia and Vitex negundo are used by tribals for the treatment of headache.

The tribal people of G.Udayagiri hill forest of Kondhamal district use 21 plant species to treat stomach problems, 09 plants for the treatment of jaundice. In the present study only Abutilom indicum was used for the treatment of jaundice. 
Abutilon indicum, Azadirachta indica, Ficus benghalensis and Terminalia arjuna were used to treat dental problems. Various studies have reported on the indigenous use of medicinal plants in the treatment of oral diseases.

Andrographis paniculata and Vinca rosea were used to treat diabetes by the local traditional healers.

The study area is rich in medicinal plant resources. An attempt was made to collect information on the traditional medicinal knowledge present with the local tribes. However, more in depth information may be explored from the tribes residing in the remote area of the G.Udayagiri. This type of study will give new impetus to the traditional system of healthcare.

Medicinal plants play an important role as they are concerned with the human health and life. Most of these plants grow wild in nature and few are cultivated. Either the whole plant or various parts like stem, root, leaf, flower, seed, bark etc. is used for the preparation of medicines under present study.

\section{TABLE -1}

Most of the Ayurvedic and Homeopathic drugs are prepared from the plants. Now some of the Allopathic medicines are also prepared from plant products. Life saving drugs like antibiotics is prepared from some fungi and bacteria (Satapathy, 1990;Singh and Sinha, 1991). Beverages are plant products which have some importance for human beings to give refreshing and delicious drinks. They act as stimulants and may be nutritive for having some amount of minerals, vitamins and other nourishing contents (Simmons, 1977).

In view of the importance of traditional medicine which provides health services to $75-80 \%$ of the world population, increased demand of herbal drugs by the pharmaceuticals and depleting natural plant resources, it is high time to document the medicinal utility of less known plants available in remote areas of country (Zaidi and Crow 2005).

G.Udayagiri hill forest is a tropical moist deciduous forest in Orissa.

Kondhamal is one of the richest botanical treasures in Orissa is under intense biotic pressure owing to forest fire, practice of podu cultivation by the tribal groups, over exploitation of medicinal plants for drugs and conversion of forest to agricultural lands. These factors of degradation result not only in the depletion of certain valuable interesting medicinal taxa but also leads to substantial reduction in the density and genetic diversity of forest cover. (Tiwari et al, 1999). This rapid damage to natural habitats, thus threatening the very survival of several indigenous species.

Unsustainable collection of above medicinal plants has placed them in threatened and vulnerable categories. Therefore, in the prevailing situation, conservation of plant resources is very important, as many of these plants, have been reduced to a greater extent. Therefore, sustainable utilization of medicinal plants is an urgent demand of the hour. Sustainable wild collection with fair trade would help to conserve the natural resources of the G.Udayagiri hill forest.

\section{Conclusion}

The survey indicated that, the study area has plenty of medicinal plants to treat a wide spectrum of human ailments. Earlier studies on medicinal plants also revealed that the economically backward local and tribal people of Kondhamal prefer folk medicines due to low cost and sometimes it is a part of their social life and culture. It is evident from the study that the knowledge of medicinal plants is limited to traditional healers, herbalists, and elderly persons who are living in rural and tribal areas. This study also points out that certain species of medicinal plants are being exploited by the local residents who are unaware of the importance of medicinal plants. This study concluded that even the accessibility of allopathic medicine for simple and complicated diseases is available, many people in the studied parts of G.Udayagiri hill forest of Kondhamal district is still continue to depend on medicinal plants, at least for some simple diseases such as, cold, cough, fever, headache snake and scorpion bites, skin diseases and tooth infections.

Due to lack of interest among the younger generation as well as their tendency to migrate to cities for lucrative jobs, there is a possibility of loosing the wealth of knowledge in the near future. It thus becomes necessary to acquire and preserve the traditional system of medicine by proper documents and identification of specimens. 
Table-1: Medicinal Plants of G.Udayagiri Hill Forest

\begin{tabular}{|c|c|c|c|c|c|c|}
\hline $\begin{array}{l}\text { Sl. } \\
\text { No. }\end{array}$ & Botanical Name & $\begin{array}{l}\text { Local } \\
\text { Name }\end{array}$ & Family & Habit & $\begin{array}{l}\text { Parts } \\
\text { Used }\end{array}$ & Medicinal uses \\
\hline 1. & Abrus precatorius $L$. & $\begin{array}{l}\text { Kaincha } \\
\text { Ko- } \\
\text { Karanji }\end{array}$ & Fabaceae & Climber & Seed & $\begin{array}{l}\text { Decoction of seed is taken } \\
\text { orally to clean the stomach } \\
\text { during indigestion and food } \\
\text { poisoning. Paste of leaf is } \\
\text { useful in scorpion bites, bone } \\
\text { fracture and stiffness of bone } \\
\text { and shoulder. }\end{array}$ \\
\hline 2. & $\begin{array}{l}\text { Abutilon indicum } \\
\text { (L.) Sweet }\end{array}$ & $\begin{array}{l}\text { Pedhipedh } \\
\text { ika }\end{array}$ & Malvaceae & Herb & Leaves & $\begin{array}{l}\text { Seven leaves with } 7 \text { black } \\
\text { pepper are ground and the } \\
\text { paste is mixed with sugar } \\
\text { candy and is taken orally for } 7 \\
\text { days to cure jaundice. }\end{array}$ \\
\hline 3. & Acacia leucophloea & $\begin{array}{l}\text { Kantasiris } \\
\text { a } \\
\text { Ko-Gohira }\end{array}$ & Mimosaceae & Tree & $\begin{array}{l}\text { Stem } \\
\text { bark }\end{array}$ & $\begin{array}{l}\text { The dried bark powdered is } \\
\text { applied on fresh wounds to } \\
\text { check bleeding. }\end{array}$ \\
\hline 4. & $\begin{array}{l}\text { Acacia pinnata (L.) } \\
\text { wild. }\end{array}$ & $\begin{array}{l}\text { Antarikant } \\
\text { a } \\
\text { Ko- } \\
\text { Kundoru }\end{array}$ & Mimosaceae & Shrub & $\begin{array}{l}\text { Leaf, } \\
\text { bark }\end{array}$ & $\begin{array}{l}\text { Juice of bark is taken orally as } \\
\text { an antidote to snake bite. Leaf } \\
\text { juice along with mother's milk } \\
\text { is given to the infants to cure } \\
\text { indigestion. }\end{array}$ \\
\hline 5. & Acalypha indica & $\begin{array}{l}\text { Indramaris } \\
\text { a } \\
\text { Ko- } \\
\text { Indramaris }\end{array}$ & Euphorbiaceae & Herb & $\begin{array}{l}\text { Leaf, } \\
\text { root }\end{array}$ & $\begin{array}{l}\text { Leaf juice is applied to cure } \\
\text { scabies. Decoction of the leaf } \\
\text { is taken orally to cure asthma, } \\
\text { bronchitis and mouth } \\
\text { infection. }\end{array}$ \\
\hline 6. & $\begin{array}{l}\text { Achyranthes aspera } \\
\text { L. }\end{array}$ & $\begin{array}{l}\text { Aparamar } \\
\text { ang } \\
\text { Ko- } \\
\text { Rusabodu }\end{array}$ & Amaranthaceae & Herb & $\begin{array}{l}\text { Leaf, } \\
\text { root }\end{array}$ & $\begin{array}{l}\text { A piece of root is crushed and } \\
\text { chewed to cure toothache. } \\
\text { Root paste and black pepper is } \\
\text { administered during cholera, } \\
\text { indigestion and diarrhoea. } \\
\text { Roots are also used in cough, } \\
\text { pyrrhoea, diarrhoea, chlorea, } \\
\text { and fever. }\end{array}$ \\
\hline 7. & $\begin{array}{l}\text { Adhatoda vasica } \\
\text { Nees. }\end{array}$ & Basanga & Acanthaceae & Shrub & $\begin{array}{l}\text { Leaf, } \\
\text { stem }\end{array}$ & $\begin{array}{l}\text { Plant decoction with honey is } \\
\text { prescribed twice daily in } \\
\text { empty stomach for } 7 \text { days to } \\
\text { cure jaundice. Root bark } \\
\text { decoction with honey is taken } \\
\text { orally in empty stomach to } \\
\text { cure asthma. Decoction of the } \\
\text { leaves and root is taken along } \\
\text { with ginger for cough and } \\
\text { gonorrhoea, constipation and } \\
\text { malaria. }\end{array}$ \\
\hline 8. & $\begin{array}{l}\text { Aegle marmelos (L.) } \\
\text { Corr }\end{array}$ & $\begin{array}{l}\text { Bela } \\
\text { Ko-Bella }\end{array}$ & Rutaceae & Tree & $\begin{array}{l}\text { Leaf, } \\
\text { fruit }\end{array}$ & $\begin{array}{l}\text { Powder of dried unripe fruits } \\
\text { is taken with water, twice } \\
\text { daily, to cure chronic } \\
\text { dysentery and ulceration in } \\
\text { stomach. Leaf juice is taken } \\
\text { orally, thrice a day, to reduce } \\
\text { high fever. Root paste is used } \\
\text { to cure rheumatism. }\end{array}$ \\
\hline 9. & $\begin{array}{l}\text { Ageratum } \\
\text { conyzoides }\end{array}$ & Pokasungha & Asteraceae & Herb & Leaf & $\begin{array}{l}\text { Leaf juice is applied to cure } \\
\text { abscess, boils, itches, cuts and } \\
\text { wounds. }\end{array}$ \\
\hline 10. & $\begin{array}{l}\text { Alangium lamarckii } \\
\text { Thw. Enum. }\end{array}$ & $\begin{array}{l}\text { Ankula } \\
\text { Ko- Dhala } \\
\text { Ankola }\end{array}$ & Alangiaceae & Tree & $\begin{array}{l}\text { Leaf, } \\
\text { root, } \\
\text { bark }\end{array}$ & $\begin{array}{l}\text { Leaf poultice is applied on } \\
\text { joints to get relief from } \\
\text { rheumatism. Decoction of the } \\
\text { bark is taken twice daily, to } \\
\text { cure constipation. Decoction } \\
\text { of the root is taken to expel } \\
\text { worms from the intestine. }\end{array}$ \\
\hline
\end{tabular}




\begin{tabular}{|c|c|c|c|c|c|c|}
\hline 11. & $\begin{array}{l}\text { Albizia lebbeck (L.) } \\
\text { Benth. }\end{array}$ & $\begin{array}{l}\text { Sirsa } \\
\text { Ko- Sidjui }\end{array}$ & Mimosaceae & Tree & $\begin{array}{l}\text { Root, } \\
\text { bark, } \\
\text { gum }\end{array}$ & $\begin{array}{l}\text { Decoction of the bark is taken } \\
2-3 \text { times per a day to prevent } \\
\text { bleeding from piles. Powdered } \\
\text { gum is taken with water to } \\
\text { prevent and cure night } \\
\text { blindness. }\end{array}$ \\
\hline 12. & Aloe vera & Ghikuanari & Liliaceae & Herb & Leaf & $\begin{array}{l}\text { Leaf pulp is used to promote } \\
\text { menstrual flow, to kill worms } \\
\text { from the body. The juice of } \\
\text { leaves is applied on eczema, } \\
\text { cut s, burns. }\end{array}$ \\
\hline 13. & $\begin{array}{l}\text { Alstonia scholaris } \\
\text { (L.) R.Br. }\end{array}$ & Chhatina & Apocynaceae & Tree & Leaves & $\begin{array}{l}\text { Decoction of leaves kills lice } \\
\text { on head. It is used as an } \\
\text { antidote to snake bite. }\end{array}$ \\
\hline 14. & $\begin{array}{l}\text { Andrographis } \\
\text { paniculata (Burm.f.) } \\
\text { Nees }\end{array}$ & $\begin{array}{l}\text { Bhuinimba } \\
\text { Ko- } \\
\text { Kalmeg }\end{array}$ & Acantahceae & Herb & Leaf & $\begin{array}{l}\text { Leaf juice is taken orally for } \\
\text { the treatment of malaria, and } \\
\text { to kill intestinal worms. Dry } \\
\text { leaf powder is used as } \\
\text { insecticide. }\end{array}$ \\
\hline 15. & Annona squamosa L. & $\begin{array}{l}\text { Sitaphal } \\
\text { Ko-Bederi }\end{array}$ & Annonaceae & Tree & Leaf & $\begin{array}{l}\text { Leaf juice is applied on itches } \\
\text { and boils to kill the worms and } \\
\text { on wounds of cattle. Dried leaf } \\
\text { ash is used as shampoo to kill } \\
\text { the lies. }\end{array}$ \\
\hline 16. & $\begin{array}{l}\text { Anogeissus } \\
\text { acuminata (Roxb. } \\
\text { ex. DC.) Guill.\& } \\
\text { Perr. }\end{array}$ & $\begin{array}{l}\text { Phansi } \\
\text { Ko- Parsi }\end{array}$ & Combretaceae & Tree & $\begin{array}{l}\text { Leaf, } \\
\text { bark }\end{array}$ & $\begin{array}{l}\text { Leaf juice is applied as an } \\
\text { antidote to scorpion bite. } \\
\text { Poultice of the bark is applied } \\
\text { on the cuts and wounds to } \\
\text { check bleeding. }\end{array}$ \\
\hline 17. & $\begin{array}{l}\text { Anogeissus latifolia } \\
\text { (Roxb. ex. DC.) }\end{array}$ & $\begin{array}{l}\text { Dhou } \\
\text { Ko-Dhau }\end{array}$ & Combretaceae & Tree & $\begin{array}{l}\text { Leaf, } \\
\text { bark }\end{array}$ & $\begin{array}{l}\text { Leaf juice is used as an } \\
\text { antidote to scorpion bite. } \\
\text { Poultice of bark is applied on } \\
\text { wounds to prevent bleeding. }\end{array}$ \\
\hline 18. & $\begin{array}{l}\text { Aporusa octandra } \\
\text { (Bunch-Ham. Ex. D. } \\
\text { Don) A.R.Vickery }\end{array}$ & Masania & Euphorbiaceae & Tree & $\begin{array}{l}\text { Stem } \\
\text { bark }\end{array}$ & $\begin{array}{l}\text { Stem bark paste is applied to } \\
\text { rheumatism, cuts, wounds } \\
\text {,itches and bone fractured } \\
\text { area. }\end{array}$ \\
\hline 19. & $\begin{array}{l}\text { Argemone maxicana } \\
\text { L. }\end{array}$ & $\begin{array}{l}\text { Agara } \\
\text { Ko- Sundi }\end{array}$ & Papaveraceae & Herb & $\begin{array}{l}\text { Root, } \\
\text { leaf, } \\
\text { latex, } \\
\text { Seed } \\
\text { oil }\end{array}$ & $\begin{array}{l}\text { Fresh root is eaten, } 2-3 \text { times } \\
\text { daily, to reduce fever and to } \\
\text { cure skin diseases. Leaf juice } \\
\text { along with salt is applied on } \\
\text { ringworm and skin itching. } \\
\text { Latex is applied on scabies, } \\
\text { eczema, miliarca. }\end{array}$ \\
\hline 20. & $\begin{array}{l}\text { Artocarous } \\
\text { heterophyllus }\end{array}$ & Panasa & Moraceae & Tree & $\begin{array}{l}\text { Laves, } \\
\text { Latex. } \\
\text { Root }\end{array}$ & $\begin{array}{l}\text { The leaves are useful in fever, } \\
\text { boils, wounds, skin diseases. } \\
\text { The latex is useful in dysopia, } \\
\text { opthalmities and pharyngitis. , } \\
\text { snakebite and glandular } \\
\text { swellings. }\end{array}$ \\
\hline 21. & $\begin{array}{l}\text { Asparagus } \\
\text { racemosus Willd. }\end{array}$ & $\begin{array}{l}\text { Satabari } \\
\text { Ko- } \\
\text { Penhepari }\end{array}$ & Liliaceae & Climber & Root & $\begin{array}{l}\text { Extract of fresh root is boiled } \\
\text { with milk and sugar candy and } \\
\text { taken orally twice a day to } \\
\text { cure dysentery. Paste of root is } \\
\text { taken during pregnancies to } \\
\text { prevent abortion. Decoction of } \\
\text { root is given to lactating } \\
\text { mother, } 2-3 \text { times a week to } \\
\text { increase milk. }\end{array}$ \\
\hline
\end{tabular}




\begin{tabular}{|c|c|c|c|c|c|c|}
\hline 22. & $\begin{array}{l}\text { Azadirachta indica } \\
\text { A.Juss. }\end{array}$ & $\begin{array}{l}\text { Nima } \\
\text { Ko-Nimba }\end{array}$ & Meliaceae & Tree & $\begin{array}{l}\text { Leaf, } \\
\text { bark, } \\
\text { seed } \\
\text { oil }\end{array}$ & $\begin{array}{l}\text { Decoction of leaf and bark is } \\
\text { taken to cure skin diseases. } \\
\text { Poultice of leaf and bark is } \\
\text { applied on snake bite and } \\
\text { scorpion stings. Leaf juice is } \\
\text { taken in empty stomach to } \\
\text { cure diabetes. Seed oil is } \\
\text { applied on leprosy wounds } \\
\text { and on piles to check bleeding. }\end{array}$ \\
\hline 23. & $\begin{array}{l}\text { Bacopa moneri (L.) } \\
\text { Pannel. }\end{array}$ & Brahmi & Scrophulariaceae & Herb & Leaf & $\begin{array}{l}\text { Leaf juice is given in } \\
\text { diarrhoea, dysentery, and } \\
\text { cholera. Leaf paste is applied } \\
\text { on wounds, cuts, ulcers, boil } \\
\text { and venomous insects. Leaves } \\
\text { are also used to prevent } \\
\text { tumour, cancer, chicken pox } \\
\text { and epilepsy. }\end{array}$ \\
\hline 24. & $\begin{array}{l}\text { Bauhinia purpurea } \\
\text { L. }\end{array}$ & $\begin{array}{l}\text { Barada } \\
\text { Ko-Simidi }\end{array}$ & Caesalpiniaceae & Tree & Bark & $\begin{array}{l}\text { Decoction of bark is taken } 2-3 \\
\text { times daily to cure diarrhoea. }\end{array}$ \\
\hline 25. & $\begin{array}{l}\text { Bauhinia variegata } \\
\text { Linn. }\end{array}$ & & Fabaceae & Tree & & $\begin{array}{l}\text { Decoction is used } 15 \text { days to } \\
\text { cure knots of tuberculosis. }\end{array}$ \\
\hline 26. & Boerhavia diffusa $\mathrm{L}$. & Purini & Nyctaginaceae & Herb & $\begin{array}{l}\text { Leaf, } \\
\text { root }\end{array}$ & $\begin{array}{l}\text { Plant paste with black pepper } \\
\text { and applied on snake bite area. } \\
\text { Root powder with equal } \\
\text { amount of sugar candy is } \\
\text { taken to cure cough. }\end{array}$ \\
\hline 27. & Bombax ceiba L. & $\begin{array}{l}\text { Simili } \\
\text { Ko-Bura }\end{array}$ & Bombacaceae & Tree & $\begin{array}{l}\text { Root, } \\
\text { flower } \\
\text { fruit, } \\
\text { gum }\end{array}$ & $\begin{array}{l}\text { Flower and fruit paste is } \\
\text { applied on snake bite as an } \\
\text { antidote. Powder of dried gum } \\
\text { is taken with water in empty } \\
\text { stomach to cure blood } \\
\text { dysentery. }\end{array}$ \\
\hline 28. & $\begin{array}{l}\text { Breynia rhamnoides } \\
\text { (retz.) Muell. }\end{array}$ & $\begin{array}{l}\text { Jhanjika } \\
\text { Ko- } \\
\text { Jhajangi }\end{array}$ & Euphorbiaceae & Shrub & $\begin{array}{l}\text { Leaf, } \\
\text { stem }\end{array}$ & $\begin{array}{l}\text { Juice of stem is applied on eye } \\
\text { to cure conjunctivitis. Paste of } \\
\text { young leaves with sugar candy } \\
\text { is taken to cure diarrhoea. }\end{array}$ \\
\hline 29. & $\begin{array}{l}\text { Bryophyllum } \\
\text { pinnatum (Lam.) } \\
\text { Curtz. }\end{array}$ & $\begin{array}{l}\text { Hemakeda } \\
\mathrm{r} \\
\text { Ko- } \\
\text { Amarpoi } \\
\end{array}$ & Crassulaceae & Herb & Leaf & $\begin{array}{l}\text { A paste of 2-3 leave with } \\
\text { black pepper is taken with } \\
\text { water to cure diarrhoea and } \\
\text { dysentery. }\end{array}$ \\
\hline 30. & $\begin{array}{ll}\text { Buchanania lanzan } \\
\text { Spr. }\end{array}$ & Charo & $\begin{array}{l}\text { Anacardiaceae } \\
\text { Order- } \\
\text { Sapindales }\end{array}$ & Tree & $\begin{array}{l}\text { Stem } \\
\text { bark, } \\
\text { root, } \\
\text { fruit }\end{array}$ & $\begin{array}{l}\text { The powder of stem bark is } \\
\text { used to heal wounds. Roots } \\
\text { are useful in the treatment of } \\
\text { diarrhoea. Leaves are used in } \\
\text { the treatment of skin diseases. }\end{array}$ \\
\hline 31. & $\begin{array}{l}\text { Casearia graveolens } \\
\text { Dalz. }\end{array}$ & $\begin{array}{l}\text { Giridi } \\
\text { Ko-Giridi }\end{array}$ & Flacourtaceae & Shrub & $\begin{array}{l}\text { Fruit, } \\
\text { bark }\end{array}$ & $\begin{array}{l}\text { Powder of dried fruits is used } \\
\text { to kill mice and rats. Powder } \\
\text { of dried fruits is used to store } \\
\text { food grains as it is a good } \\
\text { repellent for insects. }\end{array}$ \\
\hline 32. & $\begin{array}{l}\text { Caesalpinia digyna } \\
\text { Rottl. in Ges. }\end{array}$ & $\begin{array}{l}\text { Gila } \\
\text { Ko- Retu }\end{array}$ & Caesalpiniaceae & Shrub & Leaf & $\begin{array}{l}\text { Leaf juice is taken with water } \\
\text { by the women to regulate } \\
\text { menstrual disorders. Roasted } \\
\text { leaves are also applied over } \\
\text { bruises boils, wounds and } \\
\text { insect bite. }\end{array}$ \\
\hline 33. & $\begin{array}{l}\text { Calotripis gigantea } \\
\text { R.Br. }\end{array}$ & $\begin{array}{l}\text { Arakha } \\
\text { Ko- Zelari }\end{array}$ & Asclepiadaceae & Shrubs & $\begin{array}{l}\text { Leaf, } \\
\text { root, } \\
\text { bark, } \\
\text { latex, } \\
\text { flower } \\
\text { s }\end{array}$ & $\begin{array}{l}\text { Flowers fried in cow ghee is } \\
\text { taken to reduce cold, asthma } \\
\text { and cough. Paste of root and } \\
\text { bark is applied on scorpion } \\
\text { and snake bites as an antidote } \\
\text { foe quick relief. }\end{array}$ \\
\hline 34. & Capparis zeylanica & Asadua & Capparaceae & Shrub & Leaf, & Powder of dried leaves is used \\
\hline
\end{tabular}




\begin{tabular}{|c|c|c|c|c|c|c|}
\hline & L. & Ko-Asuda & & & $\begin{array}{l}\text { Bark } \\
\text {,fruit. } \\
\text { root }\end{array}$ & $\begin{array}{l}\text { as tooth powder to stop } \\
\text { toothache. Decoction of bark } \\
\text { is taken thrice daily to cure } \\
\text { cough and asthma. }\end{array}$ \\
\hline 35. & $\begin{array}{l}\text { Careya arborea } \\
\text { Roxb. }\end{array}$ & Kumbhe & Lecythidaceae & Tree & $\begin{array}{l}\text { Bark, } \\
\text { flower } \\
\mathrm{s}\end{array}$ & $\begin{array}{l}\text { Bark juice with raw cow milk } \\
\text { is taken to cure dysentery and } \\
\text { also applied on the fractured } \\
\text { limbs. Flowers and fresh bark } \\
\text { juice is taken with honey to } \\
\text { cure cough. }\end{array}$ \\
\hline 36. & Caryota urens L. & $\begin{array}{l}\text { Salapa } \\
\text { Ko- } \\
\text { Henka }\end{array}$ & Arecaceae & $\begin{array}{l}\text { Tall } \\
\text { shrub }\end{array}$ & Sap & $\begin{array}{l}\text { Fresh sap of the plant is taken } \\
\text { early morning in empty } \\
\text { stomach to remove } \\
\text { constipation. }\end{array}$ \\
\hline 37. & Cassia fistula $\mathrm{L}$. & $\begin{array}{l}\text { Sunari } \\
\text { Ko- } \\
\text { Bhanga }\end{array}$ & Caesalpiniaceae & Tree & $\begin{array}{l}\text { Fruit, } \\
\text { bark }\end{array}$ & $\begin{array}{l}\text { Paste of fruit along with sugar } \\
\text { is taken to cure dysentery and } \\
\text { indigestion. Paste of bark is } \\
\text { applied on the forehead to } \\
\text { cure headache. Decoction of } \\
\text { fruit is taken to reduce } \\
\text { rheumatic pain. }\end{array}$ \\
\hline 38. & $\begin{array}{l}\text { Cereus pterogonus } \\
\text { Lem. Cart.Gen. Sp. }\end{array}$ & $\begin{array}{l}\text { Shiju } \\
\text { Ko- } \\
\text { Bongadaru }\end{array}$ & Catcaceae & Shrub & Stem & $\begin{array}{l}\text { Juice of the stem is applied on } \\
\text { the blisters caused due to } \\
\text { burns for cooling effects. }\end{array}$ \\
\hline 39. & $\begin{array}{l}\text { Chloroxylon } \\
\text { swietiana }\end{array}$ & $\begin{array}{l}\text { Bheru } \\
\text { Ko- } \\
\text { Sangei sali }\end{array}$ & Rutaceae & Tree & $\begin{array}{l}\text { Leaf, } \\
\text { bark }\end{array}$ & $\begin{array}{l}\text { Decoction of bark is taken } 2-3 \\
\text { times daily to cure stomach } \\
\text { pain and blood dysentery. } \\
\text { Poultice of leaf is applied on } \\
\text { joints to reduce rheumatic pain } \\
\text { and on cuts and wounds. }\end{array}$ \\
\hline 40. & $\begin{array}{l}\text { Cissampelos pareira } \\
\text { L. }\end{array}$ & $\begin{array}{l}\text { Akanabind } \\
\text { hi } \\
\text { Ko- } \\
\text { Subudhiba } \\
\text { rso } \\
\end{array}$ & Menispermaceae & Climber & $\begin{array}{l}\text { Root, } \\
\text { leaf }\end{array}$ & $\begin{array}{l}\text { Decoction of root is taken } \\
\text { orally to reduce stomach pain, } \\
\text { malaria and fever. Leaf juice } \\
\text { is used in scorpion stings, } \\
\text { leprosy, migraine and scabies. }\end{array}$ \\
\hline 41. & $\begin{array}{l}\text { Cissus } \\
\text { quadrangularis L. }\end{array}$ & $\begin{array}{l}\text { Hadabhan } \\
\text { ga }\end{array}$ & Vitaceae & $\begin{array}{l}\text { Shrub(Cl } \\
\text { imbing) }\end{array}$ & Stem & $\begin{array}{l}\text { A paste of stem is plastered } \\
\text { with castor oil in bone crack } \\
\text { and bone fracture. }\end{array}$ \\
\hline 42. & $\begin{array}{l}\text { Cleistanthus collinus } \\
\text { (Roxb) Benth. Ex. } \\
\text { Hook. f. }\end{array}$ & $\begin{array}{l}\text { Karada } \\
\text { Ko- } \\
\text { Mardang }\end{array}$ & Euphorbiaceae & Tree & $\begin{array}{l}\text { Leave } \\
\text { s, bark }\end{array}$ & $\begin{array}{l}\text { Paste of bark is applied on } \\
\text { septic wounds. Decoction of } \\
\text { fruits and leaves are taken to } \\
\text { cure acute gastro-intestinal } \\
\text { irritations. }\end{array}$ \\
\hline 43. & $\begin{array}{l}\text { Clerodendrum } \\
\text { indicum (L.) Kuntze. }\end{array}$ & Kharakhari & Verbenaceae & Shrub & Root & $\begin{array}{l}\text { Root paste with } 7 \text { black } \\
\text { pepper is taken to cure } \\
\text { mumps, mouth ulcers and } \\
\text { glossitis. }\end{array}$ \\
\hline 44. & $\begin{array}{l}\text { Costus speciosus } \\
\text { (Koenig.) Sm. } \\
\text { Trans.Lin. }\end{array}$ & $\begin{array}{l}\text { Gaigobra } \\
\text { Ko- } \\
\text { Gaigaruda }\end{array}$ & Zingiberaceae & Herb & $\begin{array}{l}\text { Rhizo } \\
\text { me, } \\
\text { root }\end{array}$ & $\begin{array}{l}\text { Paste of rhizome along with } \\
\text { curd is taken orally to cure } \\
\text { dysentery. }\end{array}$ \\
\hline 45. & $\begin{array}{l}\text { Crateva adansoni } \\
\text { DC.Prod. }\end{array}$ & $\begin{array}{l}\text { Baruna } \\
\text { Ko- } \\
\text { Kamilimar } \\
\text { mu }\end{array}$ & Capparaceae & Tree & $\begin{array}{l}\text { Leaf, } \\
\text { bark }\end{array}$ & $\begin{array}{l}\text { Leaves are chewed in tooth } \\
\text { ache. Bark paste with cow } \\
\text { urine is applied on breast for } \\
\text { lactation after child birth. }\end{array}$ \\
\hline 46. & $\begin{array}{l}\text { Curculigo } \\
\text { orchioides Gaertn }\end{array}$ & Talamuli & Hypoxidaceae & Herb & Tuber & $\begin{array}{l}\text { Tuber is made into paste and } \\
\text { applied externally as an } \\
\text { antidote to snake bite. }\end{array}$ \\
\hline 47. & $\begin{array}{l}\text { Curcuma aromatica } \\
\text { Salisb. }\end{array}$ & Palua & Zingiberaceae & Herb & Tuber & $\begin{array}{l}\text { Rhizome is useful in anorexia, } \\
\text { dyspepsia, dehydration, } \\
\text { dysentery, diarrhoea, asthma, } \\
\text { fever, utricaria and in general } \\
\text { debility. }\end{array}$ \\
\hline
\end{tabular}




\begin{tabular}{|c|c|c|c|c|c|c|}
\hline 48. & $\begin{array}{l}\text { Curcuma domestica } \\
\text { Val. }\end{array}$ & Haladi & Zingiberaceae & Herb & Tuber & $\begin{array}{l}\text { The decoction of rhizome is } \\
\text { given in bronchitis, diarrhoea } \\
\text { and intermittent fever. } \\
\text { Rhizome is also used in gall } \\
\text { stone. }\end{array}$ \\
\hline 49. & $\begin{array}{l}\text { Cuscuta reflexa } \\
\text { Roxb. }\end{array}$ & Nirmuli & Convolvulaceae & Climber & $\begin{array}{l}\text { Stem, } \\
\text { Whole } \\
\text { plant }\end{array}$ & $\begin{array}{l}\text { Plant is used in cuts, wounds, } \\
\text { burns and various skin } \\
\text { diseases. Stem decoction with } \\
\text { honey is taken in every } \\
\text { morning for } 7 \text { days to } \\
\text { epilepsy. }\end{array}$ \\
\hline 50. & $\begin{array}{l}\text { Dalbergia latifolia } \\
\text { Roxb. Pl. Corom. }\end{array}$ & $\begin{array}{l}\text { Sisso } \\
\text { Ko-Masu }\end{array}$ & Fabaceae & Tree & $\begin{array}{l}\text { Leaf, } \\
\text { bark }\end{array}$ & $\begin{array}{l}\text { Leaf juice is applied on } \\
\text { leprosy wound to cure. } \\
\text { Decoction of bark is taken to } \\
\text { cure diarrhoea and to reduce } \\
\text { obesity. }\end{array}$ \\
\hline 51. & Datura metel L. & $\begin{array}{l}\text { Kala } \\
\text { Dudura } \\
\text { Ko- } \\
\text { Dudura }\end{array}$ & Solanaceae & $\begin{array}{l}\text { Under } \\
\text { shrub }\end{array}$ & $\begin{array}{l}\text { Leaf, } \\
\text { root, } \\
\text { flower } \\
\text {, fruit }\end{array}$ & $\begin{array}{l}\text { Decoction of leaf and root is } \\
\text { used to cure influenza. Juice } \\
\text { of flower is directly put on the } \\
\text { ear to relieve earache. Poultice } \\
\text { of fruit is applied on scalp to } \\
\text { remove dandruff. }\end{array}$ \\
\hline 52. & $\begin{array}{l}\text { Dendrophthoe } \\
\text { falcata (L. f.) } \\
\text { Etting.Akad. }\end{array}$ & $\begin{array}{l}\text { Malang } \\
\text { Ko- } \\
\text { Madanga }\end{array}$ & Loranthacae & Shrub & $\begin{array}{l}\text { Stem, } \\
\text { whole } \\
\text { plant }\end{array}$ & $\begin{array}{l}\text { Paste of the whole plant is } \\
\text { applied externally twice a day } \\
\text { for seven days to cure } \\
\text { paralysis. }\end{array}$ \\
\hline 53. & $\begin{array}{l}\text { Diospyrous } \\
\text { chloroxylum Roxb. }\end{array}$ & $\begin{array}{l}\text { Kaseikoli } \\
\text { Ko-Kosai } \\
\text { koli }\end{array}$ & Ebenaceae & Tree & $\begin{array}{l}\text { Fruits, } \\
\text { twigs }\end{array}$ & $\begin{array}{l}\text { Raw fruits are chewed to stop } \\
\text { dysentery. Twigs are used as } \\
\text { tooth sticks to prevent bad } \\
\text { breath. }\end{array}$ \\
\hline 54. & $\begin{array}{l}\text { Diospyros } \\
\text { malanoxylon Roxb. }\end{array}$ & $\begin{array}{l}\text { Kendu } \\
\text { Ko-Duri }\end{array}$ & Ebenaceae & Tree & $\begin{array}{l}\text { Leaf, } \\
\text { bark }\end{array}$ & $\begin{array}{l}\text { Decoction of the bark is given } \\
\text { in diarrhoea and dysentery. } \\
\text { Decoction of the leaves is } \\
\text { taken orally to expel gases } \\
\text { from the stomach. }\end{array}$ \\
\hline 55. & Ehertia laevis Roxb. & $\begin{array}{l}\text { Masania } \\
\text { Ko- } \\
\text { Masania }\end{array}$ & Ehertiaceae & Tree & $\begin{array}{l}\text { Leaf, } \\
\text { root, } \\
\text { bark }\end{array}$ & $\begin{array}{l}\text { Decoction of the root is taken } \\
\text { orally, once a day, to cure } \\
\text { gynaecological problems. } \\
\text { Decoction of the leaves is } \\
\text { taken to cure cold and cough. }\end{array}$ \\
\hline 56. & $\begin{array}{l}\text { Erythrina variegata } \\
\text { L. }\end{array}$ & $\begin{array}{l}\text { Paladhua } \\
\text { Ko- } \\
\text { Sembed }\end{array}$ & Fabaceae & Tree & $\begin{array}{l}\text { Leaf, } \\
\text { bark }\end{array}$ & $\begin{array}{l}\text { Leaf juice mixed with rice } \\
\text { flour is taken at bed time for } 3 \\
\text { days to expel the worms. } \\
\text { Decoction of bark is taken } \\
\text { twice daily to cure blood } \\
\text { dysentery. }\end{array}$ \\
\hline 57. & $\begin{array}{l}\text { Elephantopus scaber } \\
\text { L. }\end{array}$ & $\begin{array}{l}\text { Mayurchul } \\
\text { ia }\end{array}$ & Asteraceae & Herb & Root & $\begin{array}{l}\text { Root paste along with salt is } \\
\text { taken in empty stomach in the } \\
\text { morning for } 21 \text { days to cure } \\
\text { abdomen and stomach pain. }\end{array}$ \\
\hline 58. & $\begin{array}{l}\text { Embelica ribes } \\
\text { Burm. f. }\end{array}$ & Biduanga & Myrsinaceae & Climber & Seed & $\begin{array}{l}\text { Fruit powder with honey is } \\
\text { given in helminhtiasis and } \\
\text { jaundice. Decoction of seed } \\
\text { powder is also useful in } \\
\text { headache,migraine } \\
\text { dizziness. }\end{array}$ \\
\hline 59. & Euphorbia hirta L. & $\begin{array}{l}\text { Chitakutei } \\
\text { Ko-Dudhi }\end{array}$ & Euphorbiaceae & Herb & $\begin{array}{l}\text { Leaf, } \\
\text { root, } \\
\text { whole } \\
\text { plant }\end{array}$ & $\begin{array}{l}\text { A piece of root dipped in } \\
\text { turmeric paste is tied on left } \\
\text { hand to get relief from } \\
\text { intermittent fever. Leaf juice } \\
\text { is given to the children to } \\
\text { remove worms. }\end{array}$ \\
\hline 60. & $\begin{array}{l}\text { Ficus benghalensis } \\
\text { L. }\end{array}$ & Bara & Moraceae & Tree & Bark & $\begin{array}{l}\text { Bark juice is given in empty } \\
\text { stomach, twice a day for } 3-4 \\
\text { weeks to cure fissure. }\end{array}$ \\
\hline
\end{tabular}




\begin{tabular}{|c|c|c|c|c|c|c|}
\hline 61. & Fiscus racemosa & Dimiri & Moraceae & Tree & $\begin{array}{l}\text { Root } \\
\text { sap, } \\
\text { stem } \\
\text { bark }\end{array}$ & $\begin{array}{l}\text { Root sap with sugar candy is } \\
\text { taken twice a day in empty } \\
\text { stomach to cure jaundice. } \\
\text { Stem bark paste is taken with } \\
\text { water to increase lactation. }\end{array}$ \\
\hline 62. & $\begin{array}{l}\text { Flacourtia indica } \\
\text { Merr. }\end{array}$ & $\begin{array}{l}\text { Kanteikoli } \\
\text { Ko- Meral }\end{array}$ & Flacourtiaceae & Shrub & $\begin{array}{l}\text { Root, } \\
\text { Fruit }\end{array}$ & $\begin{array}{l}\text { Fruit is taken in jaundice and } \\
\text { to cure enlarged spleen. Root } \\
\text { past is taken orally with water } \\
\text { in empty stomach for } 10-15 \\
\text { days to cure chronic abdomen } \\
\text { pain. }\end{array}$ \\
\hline 63. & $\begin{array}{l}\text { Flacourtia } \\
\text { cataphracta Roxb. }\end{array}$ & $\begin{array}{l}\text { Baincha } \\
\text { Ko- } \\
\text { Baincha }\end{array}$ & Flacourtiaceae & Tree & $\begin{array}{l}\text { Fruit, } \\
\text { bark }\end{array}$ & $\begin{array}{l}\text { Fruits are taken for a week to } \\
\text { reduce bile related problems. } \\
\text { Decoction of bark is taken to } \\
\text { increase digestion. }\end{array}$ \\
\hline 64. & $\begin{array}{l}\text { Gmelina arborea } \\
\text { Roxb. }\end{array}$ & $\begin{array}{l}\text { Gambhari } \\
\text { Ko- } \\
\text { Gumna }\end{array}$ & Verbenaceae & Tree & $\begin{array}{l}\text { Leaf, } \\
\text { fruit }\end{array}$ & $\begin{array}{l}\text { Decoction of leaf juice is } \\
\text { given } 2-3 \text { times daily for } 3-4 \\
\text { weeks to cure urinogenital } \\
\text { infections. }\end{array}$ \\
\hline 65. & $\begin{array}{l}\text { Grewia tilifolia } \\
\text { Vahl. }\end{array}$ & $\begin{array}{l}\text { Dhamana } \\
\text { Ko- } \\
\text { Dhamana }\end{array}$ & Tiliaceae & Tree & Bark & $\begin{array}{l}\text { Juice of the bark is taken } \\
\text { orally , twice daily, to cure } \\
\text { acute dysentery. }\end{array}$ \\
\hline 66. & $\begin{array}{l}\text { Hemidesmus indicus } \\
\text { R.Br. }\end{array}$ & $\begin{array}{l}\text { Anantamu } \\
\text { la } \\
\text { Ko- } \\
\text { Sugandhi }\end{array}$ & Asclepiadaceae & Herb & Root & $\begin{array}{l}\text { Root paste with } 2-3 \text { black } \\
\text { pepper is taken in } 3 \text { doses } \\
\text { daily to cure all types of } \\
\text { diarrhoea of children. }\end{array}$ \\
\hline 67. & $\begin{array}{l}\text { Holarrhena } \\
\text { antidysentrica Wall. } \\
\text { ex A.Dc.. }\end{array}$ & $\begin{array}{l}\text { Keruan } \\
\text { Ko-Kenua }\end{array}$ & Apocynaceae & $\begin{array}{l}\text { Small } \\
\text { tree }\end{array}$ & $\begin{array}{l}\text { Leaf, } \\
\text { seed, } \\
\text { bark }\end{array}$ & $\begin{array}{l}\text { Seed paste is given in water to } \\
\text { cure stomachache and } \\
\text { diarrhoea. Leaves are kept } \\
\text { over the affected area to get } \\
\text { relief from rheumatic pain. }\end{array}$ \\
\hline 68. & $\begin{array}{l}\text { Hygrophila } \\
\text { auriculata (Schum.) }\end{array}$ & $\begin{array}{l}\text { Koilekha } \\
\text { Ko- } \\
\text { Kanikanta }\end{array}$ & Acanthaceae & Herb & $\begin{array}{l}\text { Leaf, } \\
\text { seed, } \\
\text { root }\end{array}$ & $\begin{array}{l}\text { Decoction of the root with } \\
\text { honey is taken in empty } \\
\text { stomach twice a day, for } 15 \\
\text { days to get relief from body } \\
\text { ache, arthritis and rheumatism. } \\
\text { Leaf extraction is taken orally } \\
\text { to get relief from arthritis. }\end{array}$ \\
\hline 69. & $\begin{array}{l}\text { Ipoimea sepiaria } \\
\text { Koening ex. Roxb. }\end{array}$ & $\begin{array}{l}\text { Musakani } \\
\text { Ko- } \\
\text { Musakani } \\
\text { nai }\end{array}$ & Convolvulaceae & Herb & Leaf & $\begin{array}{l}\text { Juice of the leaves is taken for } \\
\text { stomach cooling. }\end{array}$ \\
\hline 70. & $\begin{array}{l}\text { Lannea } \\
\text { coromandelica } \\
\text { (Houtt.) Merr. }\end{array}$ & $\begin{array}{l}\text { Mohi } \\
\text { Ko- } \\
\text { Nanam }\end{array}$ & Anacardiaceae & Tree & Bark & $\begin{array}{l}\text { Decoction of bark is used as a } \\
\text { mouth in case of bleeding gum } \\
\text { and toothache. Paste of bark is } \\
\text { applied in ulcers to get relief. }\end{array}$ \\
\hline 71. & Lawsonia inermis L. & Manjuati & Lythraceae & Shrub, & $\begin{array}{l}\text { Root, } \\
\text { leaves, } \\
\text { flower }\end{array}$ & $\begin{array}{l}\text { Root powder with a cup of } \\
\text { water is given for } 5 \text { days in } \\
\text { jaundice and menstrual } \\
\text { disorders. Leaf juice with } \\
\text { candy is given } \\
\text { spermatorrhoea. }\end{array}$ \\
\hline 72. & Leucas aspera & Gayasa & Lamiaceae & Herb & Leaf & $\begin{array}{l}1-2 \text { drops of leaf juice is } \\
\text { poured in one of the nostrils to } \\
\text { cure migraine and headache. }\end{array}$ \\
\hline 73. & $\begin{array}{l}\text { Limonia acidissima } \\
\text { L. }\end{array}$ & Kaitha & Rutaceae & Tree & $\begin{array}{l}\text { Leave } \\
\text { s, } \\
\text { bark, } \\
\text { fruit }\end{array}$ & $\begin{array}{l}\text { Powder of dried bark is } \\
\text { applied on burns for quick } \\
\text { healing. Leaves boiled in } \\
\text { water is used to cure knee and } \\
\text { joint pain. }\end{array}$ \\
\hline 74. & $\begin{array}{l}\text { Madhuca indica } \\
\text { J.F.Gmel. }\end{array}$ & Mahula & Sapotaceae & Tree & $\begin{array}{l}\text { Flowe } \\
\text { r, bark }\end{array}$ & $\begin{array}{l}\text { Decoction of bark with honey } \\
\text { is taken daily for } 4-5 \text { days to } \\
\text { cure dysentery and diarrhoea. } \\
\text { Flowers fried with ghee is }\end{array}$ \\
\hline
\end{tabular}




\begin{tabular}{|c|c|c|c|c|c|c|}
\hline & & & & & & given to cure piles. \\
\hline 75. & Mangifera indica L. & Amba & Anacardiaceae & Tree & $\begin{array}{l}\text { Leaf, } \\
\text { fruit, } \\
\text { bark }\end{array}$ & $\begin{array}{l}\text { Paste of leaf or young fruit is } \\
\text { taken orally with water to cure } \\
\text { diarrhoea. Stem bark juice is } \\
\text { taken with water to check } \\
\text { dysentery. Young leaf juice } \\
\text { with black pepper and } \\
\text { unboiled cow milk is used to } \\
\text { cure vomiting, gastric } \\
\text { disorders, bile and acidity. }\end{array}$ \\
\hline 76. & Mimosa pudica L. & $\begin{array}{l}\text { Lajakuli } \\
\text { Ko-Lajuli }\end{array}$ & Mimosaceae & Herb & $\begin{array}{l}\text { Leaf, } \\
\text { root }\end{array}$ & $\begin{array}{l}\text { Paste of root fried with ghee is } \\
\text { applied in caries teeth to get } \\
\text { relief from toothache. Leaf } \\
\text { paste is applied on forehead to } \\
\text { get relief from headache and } \\
\text { migraine. }\end{array}$ \\
\hline 77. & $\begin{array}{l}\text { Michelia champaca } \\
\text { L. }\end{array}$ & Champa & Magnoliaceae & Tree & $\begin{array}{l}\text { Leaf, } \\
\text { stem } \\
\text { bark }\end{array}$ & $\begin{array}{l}\text { Cleaning of hair with leaf } \\
\text { decoction helps in removing } \\
\text { lies and dandruff. A decoction } \\
\text { of the bark and leaves is given } \\
\text { after childbirth; the bark is } \\
\text { used as a febrifuge. }\end{array}$ \\
\hline 78. & $\begin{array}{l}\text { Nyctanthes arbor- } \\
\text { tristis L. }\end{array}$ & Gangasiuli & Oleaceae & Shrub & $\begin{array}{l}\text { Leaf, } \\
\text { root } \\
\text { bark }\end{array}$ & $\begin{array}{l}\text { Leaf juice is poured in nostrils } \\
\text { twice a day to cure sinusitis, } \\
\text { headache and nasal bleeding. } \\
\text { Root bark decoction with } \\
\text { black pepper is taken in empty } \\
\text { stomach to check lumbago or } \\
\text { lower backache. }\end{array}$ \\
\hline 79. & $\begin{array}{l}\text { Ocimum bacilicum } \\
\text { L. }\end{array}$ & $\begin{array}{l}\text { Dahana } \\
\text { Babui } \\
\text { Tulasi }\end{array}$ & Lamiaceae & Herb & $\begin{array}{l}\text { Leaf, } \\
\text { seed }\end{array}$ & $\begin{array}{l}\text { Seeds with water is taken } \\
\text { during dysentery. Decoction } \\
\text { of leaves is given in } \\
\text { constipation. }\end{array}$ \\
\hline 80. & Ocimum sanctum $L$. & Tulsi & Lamiaceae & Herb & $\begin{array}{l}\text { Leaf, } \\
\text { root }\end{array}$ & $\begin{array}{l}\text { Decoction of leaves reduces } \\
\text { ear ache and fever. Root is } \\
\text { used in malarial fever. }\end{array}$ \\
\hline 81. & Oxalis carniculata L. & $\begin{array}{l}\text { Ambiliti } \\
\text { Ko- } \\
\text { Ambilisag } \\
\text { a }\end{array}$ & Oxalidaceae & Herb & Leaf & $\begin{array}{l}\text { Decoction of the leaves is } \\
\text { taken to cure stomach pain. }\end{array}$ \\
\hline $82 .$. & $\begin{array}{l}\text { Phoenix pusilla } \\
\text { Gaertn, }\end{array}$ & $\begin{array}{l}\text { Banakhaju } \\
\text { ri }\end{array}$ & Arecaceae & Shrub & $\begin{array}{l}\text { Leaf, } \\
\text { rhizo } \\
\text { me }\end{array}$ & $\begin{array}{l}\text { Rhizome juice is given in } \\
\text { empty stomach with water to } \\
\text { cure jaundice. Leaf juice kept } \\
\text { is taken to cure intestinal } \\
\text { worm. }\end{array}$ \\
\hline 83. & Paederia foetida $L$. & $\begin{array}{l}\text { Prasaruni } \\
\text { Ko- } \\
\text { Gandhali }\end{array}$ & Rubiaceae & $\begin{array}{l}\text { Shrub(Cl } \\
\text { imbing) }\end{array}$ & Leaf & $\begin{array}{l}\text { Leaf juice with black pepper is } \\
\text { given to prevent indigestion. }\end{array}$ \\
\hline 84. & $\begin{array}{l}\text { Pavetta tomentosa } \\
\text { Roxb. }\end{array}$ & $\begin{array}{l}\text { Pengu } \\
\text { Ko- } \\
\text { Kattapeng } \\
\end{array}$ & Rubiaceae & Shrub & Leaf & $\begin{array}{l}\text { Leaf boiled with water is } \\
\text { formented to get relief from } \\
\text { pain due to blood clot. }\end{array}$ \\
\hline 85. & $\begin{array}{l}\text { Phyllanthus } \\
\text { fraternus Webster }\end{array}$ & Badiamla & Euphorbiaceae & Herb & $\begin{array}{l}\text { Root, } \\
\text { whole } \\
\text { plant }\end{array}$ & $\begin{array}{l}\text { Root powder with black } \\
\text { pepper is taken with water to } \\
\text { cure amoebic dysentery and } \\
\text { diarrhoea of children. }\end{array}$ \\
\hline 86. & $\begin{array}{l}\text { Phyllanthus emblica } \\
\text { L. }\end{array}$ & $\begin{array}{l}\text { Amla } \\
\text { Ko- Aura }\end{array}$ & Euphorbiaceae & Tree & Fruit & $\begin{array}{l}\text { Dried fruit mixed with rock } \\
\text { salt is given to cure cough. } \\
\text { Fruit juice is taken to cure } \\
\text { liver problems. }\end{array}$ \\
\hline 87. & Plumbago indica L. & $\begin{array}{l}\text { Lal } \\
\text { Chitaparu } \\
\text { Lalchita }\end{array}$ & Plumbaginaceae & Herb & $\begin{array}{l}\text { Leave } \\
\text { s, root }\end{array}$ & $\begin{array}{l}\text { Root poultice with water is } \\
\text { taken in empty stomach for } \\
\text { abortion. In case of cuts } \\
\text { wounds and bodyache, castor } \\
\text { oil is first applied on the }\end{array}$ \\
\hline
\end{tabular}




\begin{tabular}{|c|c|c|c|c|c|c|}
\hline & & & & & & $\begin{array}{l}\text { affected parts and then } 3-4 \\
\text { leaves is applied to get relief. }\end{array}$ \\
\hline 88. & $\begin{array}{l}\text { Plumbago zeylanica } \\
\text { L. }\end{array}$ & $\begin{array}{l}\text { Dhala } \\
\text { Chitaparu } \\
\text { Ko- } \\
\text { Sitaparu }\end{array}$ & Plumbaginaceae & Herb & Root & $\begin{array}{l}\text { Poultice of root is applied } \\
\text { externally in leprosy and } \\
\text { rheumatism. Milky juice of } \\
\text { the plant is taken to reduce } \\
\text { hysteria. }\end{array}$ \\
\hline 89. & $\begin{array}{l}\text { Pongamia pinnata } \\
\text { (L.) Pierre. }\end{array}$ & Karanja & $\begin{array}{l}\text { Fabaceae } \\
\text { Fabales-DC }\end{array}$ & Tree & $\begin{array}{l}\text { Leaf, } \\
\text { fruit, } \\
\text { root }\end{array}$ & $\begin{array}{l}\text { Juice of roots with coconut } \\
\text { milk and lime water used for } \\
\text { treatment of gonorrhea .Roots } \\
\text { are also used in vaginal and } \\
\text { skin diseases, cleaning gums, } \\
\text { teeth and ulcers. }\end{array}$ \\
\hline 90. & Psidium guajava L. & $\begin{array}{l}\text { Piluli } \\
\text { Ko-Mehu }\end{array}$ & Myrtaceae & Tree & Twig & $\begin{array}{l}\text { Paste of tender twig with cold } \\
\text { water is given to cure blood } \\
\text { dysentery. }\end{array}$ \\
\hline 91. & $\begin{array}{l}\text { Rauwolfia } \\
\text { serpentina Benth. } \\
\text { Ex. Kurz. }\end{array}$ & $\begin{array}{l}\text { Patalagaru } \\
\text { da } \\
\text { Ko- } \\
\text { Chhedaba } \\
\text { y }\end{array}$ & Apocynaceae & Shrub & $\begin{array}{l}\text { Leave } \\
\mathrm{s} \text {, root }\end{array}$ & $\begin{array}{l}\text { Root paste with honey is taken } \\
\text { in empty stomach for } 21 \text { days } \\
\text { to cure mental disorder. Juice } \\
\text { of leaves is applied on eye to } \\
\text { cure cornea. Root is also used } \\
\text { as an antidote to snake bite. }\end{array}$ \\
\hline 92. & $\begin{array}{l}\text { Ricinus communis } \\
\text { L. }\end{array}$ & $\begin{array}{l}\text { Jada } \\
\text { Ko- Kala }\end{array}$ & Euphorbiaceae & Shrub & $\begin{array}{l}\text { Stem } \\
\text { bark, } \\
\text { oil, }\end{array}$ & $\begin{array}{l}\text { Castor oil is used as a message } \\
\text { for easy delivery. Latex is } \\
\text { applied on skin to cure } \\
\text { scabies. }\end{array}$ \\
\hline 93. & $\begin{array}{l}\text { Sapindus emarginata } \\
\text { Vahl. }\end{array}$ & $\begin{array}{l}\text { Ritha } \\
\text { Ko- } \\
\text { Maktaman } \\
\text { ji }\end{array}$ & Sapindaceae & Tree & $\begin{array}{l}\text { Leaf, } \\
\text { fruit, } \\
\text { seed }\end{array}$ & $\begin{array}{l}\text { Fruit juice is used as nasal } \\
\text { drop to cure headache and } \\
\text { migraine. Seed powder is used } \\
\text { as Snuff in epileptic fit. }\end{array}$ \\
\hline 94. & $\begin{array}{l}\text { Schleichera } \\
\text { oleosa(lour.) Oken }\end{array}$ & Kusuma & Sapindaceae & Tree & $\begin{array}{l}\text { Leave } \\
\text { s,stem } \\
\text {,bark, } \\
\text { oil }\end{array}$ & $\begin{array}{l}\text { Bark and stem extracts are } \\
\text { used for wounds and to slow } \\
\text { down cancer cell growth. } \\
\text { Leaves stimulate hair growth. }\end{array}$ \\
\hline 95. & $\begin{array}{l}\text { Semacarpus } \\
\text { anacardium L. f. }\end{array}$ & $\begin{array}{l}\text { Kalabhalia } \\
\text { Ko-Bhalia }\end{array}$ & Anacardiaceae & Tree & $\begin{array}{l}\text { Fruit, } \\
\text { seed } \\
\text { oil }\end{array}$ & $\begin{array}{l}\text { Seed oil is applied on cuts and } \\
\text { wounds, leprosy, and } \\
\text { rheumatism for healing. Fruits } \\
\text { boiled with rice is taken once } \\
\text { daily for 3-4 weeks to cure } \\
\text { arthritis. }\end{array}$ \\
\hline 96. & $\begin{array}{l}\text { Sensevieria } \\
\text { roxburghiana Shultz. } \\
\text { \& Shultz }\end{array}$ & Murga & Agavaceae & Herb & Stem & $\begin{array}{l}\text { Juice of tender shoot is taken } \\
\text { orally to cure throat infection } \\
\text { and in earache. }\end{array}$ \\
\hline 97. & $\begin{array}{l}\text { Shorea robusta } \\
\text { Gaertn } \mathrm{f} \text {. }\end{array}$ & $\begin{array}{l}\text { Sala } \\
\text { Ko- } \\
\text { Sarjom }\end{array}$ & $\begin{array}{l}\text { Dipterocarpacea } \\
\text { e }\end{array}$ & Tree & $\begin{array}{l}\text { Oleore } \\
\text { sin, } \\
\text { bark }\end{array}$ & $\begin{array}{l}\text { Oleoresin (Jhuna) with water } \\
\text { and black pepper is given in } \\
\text { diarrhoea. Bark paste is used } \\
\text { as an antidote to insect, dog } \\
\text { and jackal bites. }\end{array}$ \\
\hline 98. & Sida acuta Burm. f. & $\begin{array}{l}\text { Bajramuli } \\
\text { Ko- Bariar }\end{array}$ & Malvaceae & Herb & $\begin{array}{l}\text { Leaf, } \\
\text { flower } \\
\text { root }\end{array}$ & $\begin{array}{l}\text { Juice of the leaf is taken to } \\
\text { check diarrhoea. Paste of the } \\
\text { root is applied for bone } \\
\text { fracture. }\end{array}$ \\
\hline 99. & $\begin{array}{l}\text { Solanum } \\
\text { virginianum pers. }\end{array}$ & $\begin{array}{l}\text { Bhejibaiga } \\
\text { na } \\
\text { Ko- } \\
\text { Ankuranti }\end{array}$ & Solanaceae & Herb & $\begin{array}{l}\text { Root, } \\
\text { fruit, } \\
\text { leaf, } \\
\text { flower }\end{array}$ & $\begin{array}{l}\text { Leaf juice with black pepper } \\
\text { and honey is taken in empty } \\
\text { stomach for a week to cure } \\
\text { cough and tonsillitis. Flowers } \\
\text { fried in ghee is chewed } \\
\text { everyday to cure asthma. }\end{array}$ \\
\hline 100. & Streblus asper Lour. & $\begin{array}{l}\text { Sahada } \\
\text { Ko-sara }\end{array}$ & Moraceae & Tree & Bark & $\begin{array}{l}\text { Decoction of the bark is taken } \\
\text { to cure fever. Milky juice is } \\
\text { applied on chapped hands and } \\
\text { sore heals. }\end{array}$ \\
\hline
\end{tabular}




\begin{tabular}{|c|c|c|c|c|c|c|}
\hline 101. & $\begin{array}{l}\text { Solanum } \\
\text { xanthocarpum } \\
\text { Schrad \& Wend. }\end{array}$ & $\begin{array}{l}\text { Bheji } \\
\text { Baigana }\end{array}$ & Solanaceae & Herb & $\begin{array}{l}\text { Root, } \\
\text { seeds, } \\
\text { leaves }\end{array}$ & $\begin{array}{l}\text { The decoction of the root is } \\
\text { useful to expel worms from } \\
\text { the intestine, bronchitis, } \\
\text { asthma, fever and lumbago. } \\
\text { Decoction of seeds is given in } \\
\text { asthma, cough, boils and } \\
\text { scabies. }\end{array}$ \\
\hline 102. & $\begin{array}{l}\text { Strychnous nox- } \\
\text { vomica L. }\end{array}$ & $\begin{array}{l}\text { Kochila } \\
\text { Ko-Kara }\end{array}$ & Loganiaceae & Tree & $\begin{array}{l}\text { Seed, } \\
\text { stem } \\
\text { bark }\end{array}$ & $\begin{array}{l}\text { Bark of root is used for } \\
\text { cholera and stem bark is used } \\
\text { for cure dysentery and } \\
\text { dyspepsia. Extraction of } \\
\text { leaves cure skin diseases. }\end{array}$ \\
\hline 103. & $\begin{array}{l}\text { Swertia angustifolia } \\
\text { Buch. Ham.ex. D. } \\
\text { Don }\end{array}$ & $\begin{array}{l}\text { Chiretia } \\
\text { Ko- } \\
\text { Bongamar } \\
\text { icha }\end{array}$ & Gentianaceae & Herb & $\begin{array}{l}\text { Leave } \\
\text { s, } \\
\text { stem, } \\
\text { whole } \\
\text { plant }\end{array}$ & $\begin{array}{l}\text { Decoction of the plant is given } \\
\text { to expel worms from intestine. } \\
\text { Decoction of leaf and stem is } \\
\text { given to cure malaria fever. }\end{array}$ \\
\hline 104. & $\begin{array}{l}\text { Syzygium cumini } \\
\text { (L.) Skeels. }\end{array}$ & Jamu & Myrtaceae & Tree & & \\
\hline 105. & $\begin{array}{l}\text { Tephrosia villosa } \\
\text { Pers. }\end{array}$ & $\begin{array}{l}\text { Kulthia } \\
\text { Ko- } \\
\text { Piderkalat } \\
\text { a }\end{array}$ & Fabaceae & Shrub & Root & $\begin{array}{l}\text { Root paste with raw milk is } \\
\text { taken in empty stomach to } \\
\text { cure cold fever and typhoid. }\end{array}$ \\
\hline 106. & $\begin{array}{l}\text { Tamarindus indica } \\
\text { L. }\end{array}$ & $\begin{array}{l}\text { Tentuli } \\
\text { Ko- } \\
\text { Kaiyan }\end{array}$ & Caesalpiniaceae & Tree & $\begin{array}{l}\text { Leaf. } \\
\text { fruit, } \\
\text { flower }\end{array}$ & $\begin{array}{l}\text { Dried flowers with sugar is } \\
\text { taken to check blood } \\
\text { dysentery. Poultice of leaf is } \\
\text { applied on boils for quick } \\
\text { burst. }\end{array}$ \\
\hline 107. & $\begin{array}{l}\text { Terminalia arjuna } \\
\text { (DC.) Wt.\&Arn }\end{array}$ & $\begin{array}{l}\text { Arjuna } \\
\text { Ko- } \\
\text { Yarramad } \\
\text { di }\end{array}$ & Combretaceae & Tree & $\begin{array}{l}\text { Leave } \\
\text { s, bark }\end{array}$ & $\begin{array}{l}\text { Decoction of leaves cures } \\
\text { diabetes. Bark paste is applied } \\
\text { to cure bone fracture. }\end{array}$ \\
\hline 108. & $\begin{array}{l}\text { Terminalia chebula } \\
\text { Retz. }\end{array}$ & $\begin{array}{l}\text { Harida } \\
\text { Ko-Rola }\end{array}$ & Combretaceae & Tree & $\begin{array}{l}\text { Leaf, } \\
\text { bark, } \\
\text { fruit }\end{array}$ & $\begin{array}{l}\text { The decoction of bark cures } \\
\text { fractures, ulcers, asthma, } \\
\text { cough and jaundice. The juice } \\
\text { of fresh leaves cures ear pain. . } \\
\text { Decoction of fruit is used to } \\
\text { cure mouth ulcer. }\end{array}$ \\
\hline 109. & $\begin{array}{l}\text { Terminalia bellirica } \\
\text { (Gaertn.) Roxb. }\end{array}$ & $\begin{array}{l}\text { Bahada } \\
\text { Ko- } \\
\text { Lupung }\end{array}$ & Combretaceae & Tree & $\begin{array}{l}\text { Seed, } \\
\text { Bark }\end{array}$ & $\begin{array}{l}\text { Extraction of bark relieves } \\
\text { sprains. Seed extract cures } \\
\text { asthma. }\end{array}$ \\
\hline 110. & $\begin{array}{l}\text { Tephrosia purpurea } \\
\text { (L.) Pears. }\end{array}$ & $\begin{array}{l}\text { Kolathia } \\
\text { ponhra }\end{array}$ & Fabaceae & Shurb & Root & $\begin{array}{l}\text { Decoction of roots control } \\
\text { stomach ache. }\end{array}$ \\
\hline 111. & $\begin{array}{l}\text { Tinospora cordifolia } \\
\text { (Willd.) Hook.f. \& } \\
\text { Thomas. }\end{array}$ & $\begin{array}{l}\text { Guluchi } \\
\text { Ko- } \\
\text { Gurusilai }\end{array}$ & Menispermaceae & Climber & $\begin{array}{l}\text { Leaf, } \\
\text { stem, } \\
\text { root }\end{array}$ & $\begin{array}{l}\text { Extraction of leaves improve } \\
\text { fertility and decoction of } \\
\text { leaves cures malaria fever. } \\
\text { Stem decoction is used to } \\
\text { check stomach pain. }\end{array}$ \\
\hline 112. & $\begin{array}{l}\text { Trichodesma } \\
\text { indicum R.Br. }\end{array}$ & $\begin{array}{l}\text { Raktachui } \\
\mathrm{n}\end{array}$ & Boraginaceae & & $\begin{array}{l}\text { Leaf, } \\
\text { root }\end{array}$ & $\begin{array}{l}\text { Leaf paste is applied on the } \\
\text { cuts and wounds for quick } \\
\text { healing. Root paste is used for } \\
\text { body ache and anasarca. }\end{array}$ \\
\hline 113. & $\begin{array}{l}\text { Vanda roxburghii } \\
\text { R.Br }\end{array}$ & $\begin{array}{l}\text { Rasna } \\
\text { Ko- } \\
\text { gachcho } \\
\text { janaya }\end{array}$ & Orchidaceae & Herb & $\begin{array}{l}\text { Stem, } \\
\text { flower } \\
\text {, seeds }\end{array}$ & $\begin{array}{l}\text { Crushed seeds are eaten to } \\
\text { expel worms. Decoction of } \\
\text { plant is useful in gout, and } \\
\text { rheumatic arthritis. Leaf paste } \\
\text { is given in psoriasis. }\end{array}$ \\
\hline 114. & Vinca rosea & Sadabahar & Apocynaceae & Herb & Leaf & $\begin{array}{l}\text { It is used in case of nosebleed, } \\
\text { bleeding gums, mouth ulcers } \\
\text { and sore throats. The herb is } \\
\text { also effective in the treatment } \\
\text { of diabetes and different types } \\
\text { of cancers. }\end{array}$ \\
\hline 115. & Vitex negudo L. & $\begin{array}{l}\text { Begunia } \\
\text { Ko- }\end{array}$ & Verbenaceae & Shrub & $\begin{array}{l}\text { Leaf, } \\
\text { stem }\end{array}$ & $\begin{array}{l}\text { Decoction of leaves is taken } \\
\text { once for } 2 \text { weeks, to cure }\end{array}$ \\
\hline
\end{tabular}




\begin{tabular}{|c|l|l|l|l|l|l|}
\hline & & Nirgundi & & & & $\begin{array}{l}\text { diabetes. Stem sap with } \\
\text { sesame oil is poured into ear } \\
\text { to cure otalgia and supurative } \\
\text { otitis media. }\end{array}$ \\
\hline 116. & $\begin{array}{l}\text { Withania somnifera } \\
\text { Dunal. }\end{array}$ & $\begin{array}{l}\text { Aswagand } \\
\text { ha }\end{array}$ & Solanaceae & Shrub & Root & $\begin{array}{l}\text { Burnt root powder with butter } \\
\text { taken everyday early } \\
\text { morning to cure asthma. }\end{array}$ \\
\hline 117. & $\begin{array}{l}\text { Xylia xylocarpa } \\
\text { (Roxb.) Taub. }\end{array}$ & $\begin{array}{l}\text { Kongra } \\
\text { Ko-Tingna }\end{array}$ & Mimosaceae & Tree & $\begin{array}{l}\text { Bark, } \\
\text { seed } \\
\text { oil }\end{array}$ & $\begin{array}{l}\text { Decoction of the bark is taken } \\
\text { twice in a week to expel worm } \\
\text { from the intestine. Seed oil is } \\
\text { applied in rheumatic pain to } \\
\text { get relief. }\end{array}$ \\
\hline 118. & $\begin{array}{l}\text { Zingiber officinale } \\
\text { Rosc. }\end{array}$ & Ada & Zingiberaceae & Herb & $\begin{array}{l}\text { Rhizo } \\
\text { me }\end{array}$ & $\begin{array}{l}\text { Juice of rhizome mixed with } \\
\text { mustard oil is poured into ear } \\
\text { to cure supurative otitis media. }\end{array}$ \\
\hline 119. & $\begin{array}{l}\text { Zingiber purpurem } \\
\text { Rosc. Trans. Linn. }\end{array}$ & $\begin{array}{l}\text { Ramakeda } \\
\mathrm{r}\end{array}$ & Zingiberaceae & Herb & $\begin{array}{l}\text { Rhizo } \\
\text { me }\end{array}$ & $\begin{array}{l}\text { Paste of rhizome is taken with } \\
\text { water in snake bite. Paste is } \\
\text { alsplied locally on } \\
\text { also } \\
\text { scorpion and snake bite. }\end{array}$ \\
\hline 120. & $\begin{array}{l}\text { Zingiber zerumbet } \\
\text { Burm. f. }\end{array}$ & Gada & Zingiberaceae & Herb & $\begin{array}{l}\text { Rhizo } \\
\text { me }\end{array}$ & $\begin{array}{l}\text { Rhizome is useful in cough, } \\
\text { cold, asthma, bronchitis, } \\
\text { worms, leprosy, and other skin } \\
\text { diseases. }\end{array}$ \\
\hline
\end{tabular}

\section{References}

[1] Harshberger,J.W., 1896. The Purpose of Ethnobotany. Bot. Gaz., 21: 146-158.

[2] Akerele O. 1992. WHO guideline for assessment of herbal medicines. Fitoterapia 63, 99-118.

[3] Subramoniam, A. and Pushpangadan, P. 1995. Ethnopharmacological validation of traditional medicines. In: Glimpses of Indian Ethno-pharmacology by Pushpangadan P, Nyman U, George V, (ed.). TBGRI, Thiruvananthapuram, pp. 351-360.

[4] Krishna Kumar A. and Katakam A. 2002. Credit for conservation. Frontline 19: 9-22.

[5] Sandhya, B., Thomas, S., Isabel, W. and Shenbagarathai, R. 2006. Ethnomedicinal plants used by the Valaiyan community of Piranmalai Hills (Reserved Forest), Tamil Nadu, India. - A pilot study. African journal of Traditional, Complementary and Alternative Medicines, 3(1): 101-114.

[6] Jain, S.K., 1987. A Manual of Ethnobotany. Scientific Publishers, Jodhpur, India. ISBN: 8185046603.

[7] Jain, S.K., 1991. Dictionary of Indian Folk Medicine and Ethnobotany. Deep Publications, New-Delhi. ISBN: 8185622000.

[8] Pal,D.C. and Srivastava,J.N.(1979):Priliminary Notes on the Ethnobotany of Singhbhum Distict, Bull, Bot.Surv,India.18:247-280. Plants for the control CEE-NFS(Centre for Environment Education News and Feature Service, Ahmedabad)News IV 37.169 pp1.

[9] Sahaia,V.B,(1982): wildlife in India, Nataj,Dehadun,India.

[10] Jain, S.K.1991. Some magico-religious beliefs about plants among Adibasis of Orissa. Adibasi 12:38-44.

[11] Zaidi MA, Crow SA 2005. Biologically active traditional medicinal herbs from Balochistan, Pakistan. J. Ethnopharmacol, 96: 331334

[12] Tiawari et al. 1999. References of Orissa Enterprising Publisher, an India State of Eastern Region, Bhubaneswar Orissa, India.pp-8.

[13] Tiawari et al.1999. References of Orissa Enterprising publisher, an India State of Eastern Region, Bhubaneswar Orissa ,India. pp-8

[14] Simmons,i.g., (1977) : Ecology of Natural Resources Eward Arnold, London.

[15] Haines,H.H.,(1978): The Botany of Bihar and Orissa.

[16] Chakabaty,T.(1980) : Scince Spectrum Medicines from Plants, Science Reporter17(6)397:399. 